\title{
Worship and culture: endogenous and exogenous factors in a local church
}

\author{
Pierre Hegy ${ }^{1}$ (D)
}

Received: 23 December 2020 / Accepted: 30 April 2021 / Published online: 31 May 2021

(c) The Author(s), under exclusive licence to Springer Nature Switzerland AG 2021

\begin{abstract}
Since the times of Karl Marx, George Frazer and Emile Durkheim the relationship between worship and culture has been as central issue, and so it is today since 9/11. In the Roman Catholic tradition, the council of Vatican II has defined worship in reference to the endogenous dimensions of the liturgy, with little awareness of outside factors. This paper examines worship in a Catholic parish, characterized by a dynamic Latino minority within a dominantly traditional Italian American population. The endogenous variables of ethnicity and clergy dominance are not recognized while the exogenous variables of national attendance decline, ineffective institutional faith transmission, religious individualism, consumerism, and secularism are ignored. This is so because the clergy defines its responsibility only in reference to the ritual part of the liturgy, not singing and devotions. More generally, the resistance to change can be explained in terms of an ideology of self-preservation, in the form of clerical professionalization and the privatization of worship. The prevalence of ideology in the whole society today, not just religion, call for a greater awareness of the importance of ideology in cultural studies.
\end{abstract}

Keywords Worship and culture $\cdot$ Roman Catholic worship · Latino practices · Endogenous and exogenous variables

\section{The worship and culture relationship}

The relationship between worship and culture is a central issue in both anthropology and sociology. Since the early days of George Frazer, anthropologists have been confronted with the meaning of rituals in reference to the local culture and Western secular philosophy. Sociologist have similarly been confronted, since the days of Durkheim's theory of the social original of religion, with the relationship between religious representations and social structures. This research trend produced

Pierre Hegy

pierre.hegy@gmail.com

1 Adelphi University, Garden City, NY 11542, USA 
meta-theories about worship-in-general which blossomed in sociology in the longheld paradigm of secularization. Locally and internationally, religion was expected to fade away under the pressure of social differentiation, individualism privatization and scientific rationality, as summarized in Bruce's (2002) God is Dead. Today we have become suspicious of top-town metatheories like that of secularization. We must rebuild the relationship between worship and culture from the bottom up, more specifically in reference to endogenous and exogenous variables.

In the past most social sciences tended to concentrate on endogenous (or internal) variables in their fields of research, for instance, pointing to problems internal to the family in family studies, internal to education in the study of education, internal to personal development in the study of occupational achievement. It is only in the 1960s with Bowen's (1978) study of schizophrenic children that psychology included exogenous factors in the analysis of individual mental health. It is also in the 1960s that Blau and Duncan (1967) showed the importance of the exogenous variables (the father's education and occupation) on the achievements of the son. Today Blau and Duncan's five variables of occupational attainment make possible a comparative analysis of the endogenous and exogenous variables in various countries (Lancaster 1971). Similarly, before the 1960s, European sociologie religieuse understood religion mainly in reference to church attendance and religious practices. It is only with the work of Stark and Glock (1970) in the 1960s that religion came to be analyzed as both a dependent variable affected by exogenous factors and as an independent variable that must be explained from within (Stark and Glock 1970).

\section{Endogenous and exogenous dimensions in Roman Catholic worship}

The above review suggests that outside factors are known first and when these have been dealt with, research moves to the investigation of outside factors. One would expect this to be the case in religion. Thus, the decline of religious attendance in the Roman Catholic Church has been known since the 1960s. One would expect that this issue has been addressed since, and that more recently some outside factors have been taken into consideration.

The purpose of this paper is to apply endogenous and exogenous variables to the analysis of worship in a given church. More specifically, in this paper "worship" refers to the Roman Catholic liturgy of the Mass. While the various dimensions of religiosity are seen today as affected by both internal and external factors, worship itself tends to be seen as unaffected by the outside world, as in the case study to be presented below. Orthodox Sabbath services and Sunday Roman Catholic Masses are the same all over the world, hence how could they be affected by their social environment? Our first step is to investigate why this is so, more specifically in the Catholic culture.

In the Roman Catholic Church, worship usually refers to the liturgy and its endogenous aspects. The Constitution of the Sacred Liturgy of Vatican II (Abbott 1966) described the following endogenous dimensions: the Eucharist and the other sacraments (47-82), the divine office (83-101), the liturgical year (102-111), sacred music (112-121), the sacred arts (122-129), popular devotions (13), active 
participation of the faithful (14), the importance of scripture (24), and the homily (52). The Vatican II reform is generally considered a success and most people would agree with Pope Francis that it is "irreversible" (O'Connell 2017).

Because we are given a list of the basic endogenous variables of the liturgy, we do not need a theoretical definition to find them. But we are confronted with a new question: having been clearly defined fifty years ago, have they been implemented? At San Rocco, as we will find out, these variables (e.g., singing, active participation, devotions) are generally ignored. Hence our research takes a new turn: why is this so?

The importance of exogenous variables tends to be overlooked in Catholic liturgical studies because in Catholic scholarly research "worship" is often discussed in the abstract (as Catholic worship in general), rather than in reference to concrete Sunday celebrations. In fact, most published research is theoretical, historical, or theological, not in reference to actual parish Sunday liturgies. The study of worship is also fragmented into separate scholarly societies: liturgical societies tend to concentrate on texts and rituals (e. g., the Society for Catholic Liturgy and the North American Academy of Liturgy), homiletic societies discuss preaching theories and theologies (e. g., the Academy of Homiletics and the Societas Homiletica), and musicians share musical innovations in meetings of their own (e.g., the Yale Institute of Sacred Music). The Notre Dame study of parish life the late 1970s included both endogenous (e. g. worship) and exogenous variables (e. g. politics), but more recent studies have shown less interest in the various dimensions. The Notre Dame study (Leege and Gremillion 1984 to 1989) involving 19,000 Catholic parishes offered reports on religious rituals and parish activities (\# 3), parish participation and individual needs (\#4), the liturgy (\#5), parish services (\#8), religious education (\# 14), review of the post-Vatican II accomplishments (\#15), and parish participation in politics and civic life (\#11). Since then, parish studies have become more specialized. Thus, the recent CARA Catholic Parishes of the $21^{\text {st }}$ Century (Zech et al. 2017) has chapters on demographics, leadership, administration, finances, and socio-economic characteristics of people in the pews, but nothing on worship, the sacraments, religious education, and attendance decline. The more recent American Parishes. Remaking Local Catholicism (Adler et al. 2019) has nothing on the liturgy. The findings about five California parishes in Sense of the Faithful (Baggett 2003) are presented in chapters on the self, the institution, community, and the civil society, but not worship. Why is this so? One can only speculate that it is the emphasis on quantitative research prevalent in the last fifty years that explains the lack of interest in the qualitative understanding of worship.

One more factor that mitigates the importance of exogenous variables is the general tendency in the Roman Catholic Church to identify the liturgy with its text, rituals, and published music, and discuss them in theological or historic terms; as a consequence, the actual performance of the Sunday liturgies which must be evaluated empirically is ignored. While today teachers and business employees are evaluated on a regular basis, and their salaries and promotions decided accordingly, there is little or no evaluation of the liturgical performances, e. g. on the occasion of the required yearly visit by the local bishop (Coriden et al. 1985, canon 396). This absence of evaluations makes it difficult for pastors to do much about the religious 
decline in their parishes, as is the case in the church described in this paper. Quite different is the situation of non-liturgical churches when a board of elders acts as the supervisors of the church.

In the United States, numerous aspects of the outside word impinge upon religious beliefs and practices of Catholics. In 1965 the U.S. Supreme Court declared birth control legal for married women (Legal Information Institute 1965) and sometime later it became available to singles as well. Co-habitation became an acceptable alternative to marriage in most Western nations. In 1970 the state of California legalized non-fault divorce, and as a consequence the divorce rates sky-rocketed. In 1973 abortion was legalized in the U.S.in the Roe v. Wade decision. Same-sex marriage has become generally accepted, in spite of Catholic opposition. These outside factors are well known to the clergy but are considered irrelevant to worship.

At San Rocco and elsewhere, as we will see, the priests consider themselves responsible only for the liturgy understood most narrowly: only the rituals, not the singing, not the participation of the faith, and not the devotions. In short, anything but the rituals are their domain. But the outside world has already strongly affected Catholics in their trust of church authority. As documented in various surveys since 2005 , fewer than $25 \%$ of U.S. Catholics accept the moral authority of the church on matters of divorce and remarriage, birth control, abortion, homosexual behavior, and non-marital sex (D'Antonio et al. 2007, p. 96). The practice of abortion tends to be the same among U.S. Catholics and Protestants (Sullins 1999): 354-369), in spite of the strong position of the hierarchy. Divorce rates among U.S. Catholics have been similar to those of Protestants since the 1970s (Thornton 1978). The fertility rates of several Catholic countries of Europe have fallen below replacement levels in spite of the church's pronatalism. Sunday Mass attendance has drastically declined as described below. All of this is ignored by the clergy since it is not part of the liturgy in the narrow sense.

\section{Description of the church of San Rocco and its two communities}

I have selected to pursue research at San Rocco for two reasons. I was told and saw on the first visit that this parish was better than average. More importantly, it was administered by a religious congregation well-known for its intellectual and cultural initiatives. Hence, I expected the priests to be aware of the importance of internal and external factors affecting worship.

San Rocco is the pseudonym of a suburban parish in a neighborhood settled by Italian-American after WW II. It went through a succession of pastors, had to close its school about ten years after it was built, and since 1978 it is staffed by priests of a religious congregation. At the time of this study in 2019, it was served by four fulltime priests and one part-time, and four deacons. There are seven Masses every Sunday, six in English and one in Spanish. In this parish of about 1000 Sunday attenders, the small community of about 100 Latinos is barely noticeable. The Anglos worship in the main church while the Latinos attend Mass in a separate chapel, at the inconvenient time of 12:45. Only one priest speaks Spanish. No Anglo is likely to attend the Spanish 
Masses. For all practical purposes, the Latinos tend to be invisible in this mainly Italian-American neighborhood.

Here is how I came to these conclusions. In my first occasional visit to San Rocco, I was impressed by the general piety of the liturgy. Hence, I decided to conduct a study by following the methodology used in other such investigations (Hegy 2019). It consists of eight steps. (1) Collect information about the ethnographic and economic characteristics of the town, and the history and development of the parish. Steps 2-4 are observational. (2) Observe the various units of the Mass: entrance procession, confession of sins, the readings, homilies, presentation of offerings, kiss of peace, etc. and the performance of the choir, musicians, and ministers. (3) Notice all signs of closeness of God: personal piety and active participation in the liturgy. (4) Notice of all signs of social engagement among members: seating, kiss of peace, exiting. Steps 5-8 are analytic. (5) Interview pastor and staff members about their perceived role and expectations. (6) Investigate closeness to God in the parish devotional groups and ministries; the number of participants and the frequency of meetings. (7) Survey the social engagement in parish activities, the authority structure of the church, and financial giving. (8) Evaluate the effect of all variables for the future - growth or decline — of the parish. The general idea of this research is that the Sunday worship is conditioned by the religious activities or their absence from Monday through Saturday. Hence the next step-in this paperwas to undertake a secondary analysis of the endogenous and exogenous factors in the liturgy.

A first major characteristic is the great difference between Latinos and Anglos in their liturgical celebrations. At the Anglo Masses, active participation is found mostly in the front pews, with some active disengagement in the back where people may be waiting for the end of the service or even leave at communion. Strikingly different is the Spanish Mass. There, one finds a sense of community. When entering, people all greet one another, wave, and embrace because this is a small community where people know one another. All people sing to the tune of folksy Latino music. The Mass ends with the announcement of the numerous activities which all are invited to join. These differences will be further described below. The purpose of this study is to explain these differences in terms of endogenous and exogenous variables.

Church statistics are of little help. The parish staff has no clear idea of the Sunday attendance rate. Given that the parish census took place of 30 or 40 years ago and is not available, I was suggested that the Sunday attendance rate may be about $15 \%$, the common rate in this part of the country, e. g., 16\% in Boston in 2012 (America 2012). This low rate seems to be accepted without alarm by the clergy. The attitude of the priests is actually very positive. According to the pastor, "People feel at home here. They feel we care for them. About the liturgy, people are satisfied. The preaching is balanced, and well prepared. We have to take them one step further so that they grow in their faith in terms of faith seeking understanding." 


\section{The invisible variable of ethnicity}

By distinguishing between Anglo and Latino Masses I introduce a variable that is both endogenous (the Latinos are part of the parish) and also exogenous because ethnicity is invisible at San Rocco as the two communities do not recognize one another and do not mix. The Latino ethnicity is defined by language. There are many differences between Mexicans, Puerto Ricans, and Haitians but they are bound together by a common language. The so-called Anglos are ethnically very diverse, but at San Rocco the Italian form of devotion (as opposed to Irish or German) is generally accepted as their common religious culture. These ethnic differences seldom come to the fore. Even the priests do not pay attention to the differences or ignore them. Yet ethnicity seems to be a major characteristic of the parish as a whole.

At the Anglo Masses, most people hum along, without singing much aloud. There is usually no singing leader; instead, the cantor or soloist raises the arm to invite people to participate, but with little effect. At the family Mass at 9 AM, children may play a special role, as lectors or in a small choir. At the community Mass at 11 AM there is a choir of about 10 members. There is a youth Mass at 5 PM with a choir of two or three teenagers but few people in attendance in their twenties. As in many other parishes, the church usually fills up in the back first, and at all times individuals prefer to take seats away from each other.

The main Anglo characteristic is devotion, people praying individually and privately with great conviction, for instance by closing their eyes or kneeling, for instance during the consecration and the communion. Another aspect of traditional devotion is silence as an expression of respect for authority. Traditionally, children do not talk back to parents. The parishioners of San Rocco have internalized this attitude of respect through silence which may explain their reluctance to sing. One more aspect of individual devotion is praying individually after Mass in front of the statue of the Virgin Mary or St. Joseph in the back of the church; this is During Mass This is typical of the traditional spirituality of devotions.

Great inner devotion is what I noticed at my first visit. I had the impression of being back in the pre-Vatican II days. This impression was confirmed by the reaction of a newly appointed priest who noted, "This third or fourth generation Italian community reminded me of the book on the Madonna of 115 th street. The people are holding on to their tradition without the level of connectedness of the previous generations." The book referred to is Robert Orsi's study (1985) of the Italian Americans in Manhattan during the first half of the twentieth century. Another priest reported the reaction of a visitor, "A priest from Manhattan said, 'Boy, people are so quiet here. I am not used to that.' Maybe this is because the population is heavily Italian." The rest of my study confirmed these first impressions.

This seems to be "Vatican II without its spirit," as stated by a staff member, "Theologically, we have been implementing Vatican II, and people have that Vatican II mentality." Indeed, the use of English, the priest facing the assembly, and people singing along have been implemented in the 1970s. "There is a general 
comfort level in keeping things the way they are, and this is what we are stuck with here today. There is no interest in the changes taking place elsewhere." After the implementation of Vatican II reforms, worship became routine again.

Italian traditions are important in the Italian Masses, but Italian ethnicity is invisible when most people are of Italian ancestry. Very different are the following Latino ethnic traditions. (1) The Latinos have a sense of community. When entering they greet one another and embrace. At the kiss of peace, people move out of their seats and cross the aisles to shake hands. (2) There are people of all ages, with quite a few young people and mothers with babies, but the majority of adults are women. (3) There is no choir but one woman singing with a powerful voice which inspires participation. The music of the electric guitar is joyful and folksy, somewhat artistic, and the loudspeaker is loud but not overwhelming. Nearly everybody sings, including the priest. (4) The sung parts of the Mass are simple and well-known. The "Senor ten piedad" (the Kyrie) and "Gloria, gloria, gloria al Señor" are popular and sung with conviction. The guitar accompaniment is joyful and inviting. (5) At the recitation of Our Father all people hold hands in all pews and around the altar where the four acolytes and the lector gather around the priest, all holding hands. This practice is common in the charismatic movement. (6) At the end of the Mass there are announcements (but not at the Anglo Masses): one speaker invited people to join a community event and another to participate in a community ministry. Both were applauded.

Ethnicity is commonly accepted in multi-cultural parishes, but there are other more important endogenous and exogenous variables. I will consider first, lay engagement in the parish from Monday to Saturday, and the pastoral practices of the clergy, and next the exogamous factors.

\section{Differential ethnic involvement in the parish}

The Anglo parish has many devotional groups: about the miraculous medal, the recitation of the rosary, the Saint Antony devotion, the Stations of the Cross during Lent, and the adoration of the Blessed Sacrament. Their meetings take place after the morning Mass and/or during working hours; only homemakers and seniors can easily attend. Moreover, these devotions tend to be individual rather than group practices, and there is little or no organizational structure. There is also a non-parochial group of women who meet weekly for meditation; they rent space from the parish the way Alcoholics Anonymous and the Senior Center rent space from this church. There is another small prayer group that meets weekly, and an active men's spirituality group that consists mainly of seniors. There are the non-devotional groups of the boy and girl scouts, and the Father's Club which takes care of practical needs of the parish. Many of these groups are not very active and have few members.

The Latinos constitute only about $10 \%$ of the parishioners but their devotional groups are more numerous and livelier than those of the Anglos. The Cursillo group has 30 members who meet weekly for biblical reflections; they have all participated in a retreat which is often life-changing. There is a chapter of the Legion of Mary whose members are committed to pray daily and attend a weekly meeting. The most 
important aspect of their spirituality, which also affects their Sunday liturgy, is the charismatic form of prayer. The Latino charismatic prayer group has about 40 members (or $40 \%$ of the Latino parishioners) who meet for two hours every week. They begin with the rosary or the station of the cross, sing charismatic songs to the tune of Latino music, and listen to an invited speaker. Their Sunday liturgies include many charismatic practices.

For an outside observer, it is easy to notice how parish engagement during the week affects the Sunday celebration. The Anglos who participate in devotions are likely to participate in the Mass as a private devotion rather than a community celebration. The Latinos who during the week participate collectively in the structured activities of the Cursillo and the charismatic movement are likely participate in the Eucharist as a community rather than as individuals.

The attitude of the clergy in reference to people's devotions is acceptance and non-involvement. Several priests mentioned that the lay devotions are not "my type of prayer." More generally, "Priests are not involved. Probably because of our educational background, the devotional aspect does not attract us personally, although we respect them. We are centered on the liturgy." The latter is the main reason: since Vatican II the clergy has generally concentrated on its liturgical function and often neglected lay devotional practices.

The primacy of the liturgy for the clergy and their non-involvement in people's devotions are a major key to understand parish life at San Rocco and many similar parishes. For the priests, all Masses (the Anglo and the Latino Masses, and the 9 AM, the 11 AM, and the 5 PM Masses) all offer the same liturgy, and this is all that counts "We center on the liturgy;" in their view, devotions, music, and singing are up to the faithful. But why is this so? I will suggest two possible explanations, the professionalization of the priesthood and the increased privatization of worship described below.

To center on the liturgical rituals and ignore everything else seems a betrayal of Vatican II. Before this council (1962-1965) the clergy took care of all major activities of the church (singing, education, outreach, etc.). Dolan (1989) defined the past roles of the priest in social terms, as the Ombudsman (in the era from 1930 to 1954) and as Orchestra leader (from 1973 to 1989). It is only in the last thirty years that the Catholic clergy has withdrawn into its merely cultic functions. This seems the consequence of greater conservatism but also of the professionalization of the priesthood: only priests, no one else, can perform the sacred rites. This trend should explain the clerical retrenchment into the liturgy found in San Rocco and elsewhere.

\section{The unquestioned endogenous variable of clergy dominance}

This parish is directed by the executive team which consists of the four full-time priests, the four deacons, and the directors of religious education, pre-school program, outreach, and music. To a great extent it is a clergy-dominated team, by the preference of the clergy. Moreover, the religious priests share lodging and meals, hence are likely to influence decision-making as a group. This clerical structure minimizes outside voices, namely those of the parish council and the finance committee 
whose members are nominated by the pastor. Their role is advisory and they play little role in the parish. This organization of the parish is dominated by the same dichotomy as worship: the (priestly) liturgy versus the (lay) devotions, and now, the priestly management of the parish versus lay optional input.

There is no specialization among priests and deacons; they all serve on a rotating basis at Sunday liturgies, baptisms, weddings, and funerals. Although one priest is in charge of the liturgy and another of youth ministries, they are not specialized in these areas and their input is minimal. The general attitude is that church ministries are services, and nearly any priest can fulfill them. In fact, the priests sent to this parish by their religious order have no special preparation for this ministry, because the enactment of the liturgy is seen as the special function of priest, yet any ordained man can perform it. According to one priest, "the pastors [sent to administer the parish] were not prepared professionally although they were good men." The lack of pastoral preparation of the religious for parish work has been mentioned several times in my interviews. When the liturgy is the main function of the clergy, any ordained "good man" can do it.

It is common practice in the Catholic Church to rotate priests every five or six years, and more often if requested. This can have negative effects on ministries. One interviewee put it bluntly: "The religious priests rotate too quickly. The pastors and administrators stay for five years. They have different visions and different ideas, so there is nothing stable for long. The new person has new ideas, and later he is rotated. They have attempted over the years to promote their own spirituality: devotions, retreats, etc. Because they rotate, it starts and stops." In short, the clergy tends to be involved in the liturgy and the institutional church more than in the church as people of God. Let us turn to exogenous variables. I will only mention four basic ones.

\section{The exogenous variable of attendance decline}

Few parishes failed to adjust to the pandemic of COVID-19, but most seem unaware of or indifferent to the pandemic decline of church attendance, from about $75 \%$ in the U.S. in 1955-1958 to about 20\% or less today. In his recent Mass Exodus, Bullivant (2019, p. 201) found that the Sunday attendance of cradle Catholics stood at $15 \%$ in the U.S. and $13 \%$ in Britain in 2016. Religious decline does not happen progressively but in abrupt drops with each new generation. This is a general trend among Catholics and Protestants, in the U.S. as well as Europe. Each generation begins at a lower level of practice and continues at the same level during its lifespan (Chaves 2017, p. 51).

This pandemic decline has also affected San Rocco. According to a staff member, "Religious practice broke down about three generations ago. When my own children grew up, they already had friends who did not go to church. My children went to Mass every Sunday then, but now none of them is a practicing Catholic. The same is true of the children of people of my generation: most of them do not go to Mass anymore." According to another interviewee, "We have lost three generations of Catholics," that is, in the 1960s and 1970 s, as was the case nationally. From then 
on, it was a progressive dis-involvement: "I have eight nieces and nephews who are not baptized.

As of 2015 in the U.S., six Catholics left the church for every single convert to Catholicism (Chaves 2017, p. 51). This is probably also the case at San Rocco, yet there is no evangelization program and no special concern for its endangered youth.

\section{The exogenous of devotions decline}

Private devotions have been a major characteristic of Catholic life since the middle of the nineteenth century (Taves 1986). The 1940s and 1950s were the heydays of family devotions. The rosary has been for centuries the prayer of the faithful who found little inspiration in the Latin low and high Masses. In the US, the Rosary Crusade brought the whole nation to a new fervor thanks to the radio campaigns of Fr. Patrick Peyton. In 1945 he promoted the rosary at the largest radio station of the country. His program of the rosary as a family prayer was immensely popular. Another great success was that of the Enthronement of the Sacred Heart on home altars. By 1946 about half a million enthronement had taken place in 13 states; there were over 13,000 registered night adorers, and 40,000 young crusaders for this home devotion (Wikipedia n.d.).

Since then, many of these devotions have faded away. At San Rocco a few statues of saints remain in the church, but the practice of devotions has greatly declined. By showing no support for devotions, the priests have contributed to this decline. But it is the private devotions that sustained Catholic Church attendance for generations. Without such devotions, the young have little incentive to go to church. The decline of private devotions has undermined the priestly liturgies.

\section{The exogenous dimension in Catholic faith transmission}

In his study of the religious lives of American teenagers, Christian Smith came to sobering conclusions about Catholics. "On most measures of religious faith, belief, experience, and practice, Catholic teens as a whole show up as fairly weak." A main factor of weakness is the inadequacy of Catholic schools and CCD programs in the fields of religious education, formation, and ministry. Another important factor is the poor role model of parents: "the relative religious laxity of most U.S. Catholic teenagers significantly reflects the relative religious laxity of their parents." (Smith and Denton 2005, pp. 216-217; Hoge et al. 2001).

The problem is well recognized at San Rocco by the director of religious education. "The children in our program are the third generation that did not go to church as a family." Religious education includes two grade-level Masses at each grade, but less than $10 \%$ will show up because $90 \%$ of the parents do not bring them. "For parents, sending their kids to religious education once a week has replaced the obligation of the Mass. It satisfies their identity as Catholics. But the diocese is not recognizing that." After children have been confirmed, they are often not seen again. "The system is broken; it does not work. We discussed this with the diocese, but nothing 
changes. Their reply is that confirmation is not a graduation from religious ed but a sacrament; for our students, confirmation is not a sacrament but a graduation. The parents feel they have done their job." The pastor and the parish are not involved in the problem seen an outside factor about which they feel powerless.

\section{The exogenous influence of consumerism and individualism}

Consumerism is an addiction, not just the propensity to consume. As an addiction it obliterates other concerns, progressively becoming one's main concern. Other addictions are work, career, and any psychological or chemical obsession. Most often, consumerism is only a mild addiction, as consumption is a free decision at all times. The Christmas shopping frenzy starting on Black Friday is a common example. In 2019 the average American spent $\$ 668.00$ on Christmas (Market Research 2019). The problem is not just financial and the possibility of going into debt but rather, for Christians, the problem is forgetting Christ during the whole Christmas season. This applies to all parishes, including San Rocco. Shopping and other forms of addiction are not mentioned in homilies.

The protection of the individual is one the greatest achievements of the American Constitution, but individualism has come to mean the primacy of individual needs over the common good. When the priests of San Rocco accept and implicitly support devotional groups, they indirectly promote devotional individualism, their own and that of the devotional groups; social engagement was never mentioned in the homilies during the time of my observations. When priest consider the liturgy as their main and even sole responsibility, they foster clerical individualism. When the parish of San Rocco does little about poverty and inequality in its neighborhood, it fosters laissez-faire individualism. Individualism is unfriendly to the love of others.

Individualism and consumerism are clearly at work at San Rocco. Before Vatican II, the faithful came to church to pray; they came a short time before the beginning of the Mass and stayed a short time at the end. Priests were expected (and required) to do so as well. In the consumer perspective, the Mass becomes a Sunday obligation to be performed as quickly as possible. At San Rocco and elsewhere, when people arrive, they sit down, check their email or the parish bulletin, or simply wait but do not pray. And they leave as soon as possible. I was shocked to notice a mass exodus at communion (about 10-20\%); I had to sit next to the door to believe it. I was even more shocked when a priest told me he could see it from the altar, but he did not do anything about it. As soon as the Mass is over, people rush to the door-the priests first, in order to shake hands, a public relations gesture. Consumerism seems to have taken deep roots into religious practices of both the clergy and the faithful.

\section{Other Global Exogenous Variables}

The basic religious beliefs in a culture (the existence of God, life after death, judgement of the souls, heaven and earth, sacred scriptures, etc.) are conveyed by the family and the social environment rather than the churches. In Estonia and the Czech 
Republic, the basic religious beliefs are low but the first country is mainly Orthodox and the second mainly Catholic. There, the religion of the majority seems to have little effect on the basic religious beliefs of the nation. In Estonia only 13\% are absolutely sure of the existence of God, 33\% believe in heaven and 24\% in hell, and $58 \%$ consider the sacred books of the bible and Koran as mere human creations. This country is $27 \%$ Orthodox, 20\% Lutheran, and 39\% no-religion. In the Czech Republic, where $27 \%$ of the people are Catholic, $1 \%$ Protestant, and the others nonreligious, the basic beliefs are similar: $27 \%$ believe in heaven and $19 \%$ in hell, $13 \%$ are sure of the existence of God, and $65 \%$ believe the sacred books are only human creation (Pew Research Center 2017). Neither Orthodoxy in Estonia nor Catholicism in the Czech Republic have prevented the decline of these traditional beliefs. In Estonia and the Czech Republic, it is the global exogenous variables that tend to impact on local religious practices. In the U.S., it is the denominations rather than that basic religious beliefs that impact on local congregations. Thus, in mainline Protestantism the beliefs about heaven and hell stand as 80 and $60 \%$, among Catholics as 85 and $63 \%$, among evangelicals, as 88 and $82 \%$, and among the un-affiliated, 37 and 27\% (Pew Research Center 2015). Thus, when Catholics join the religious "none", their belief in hell in likely to drop from 63 to $27 \%$, and if they declare themselves atheists, this belief will further drop to 5\%. In the U.S. the basic religious beliefs are mediated by the various religious institutions and churches. In short, the basic national beliefs and the denominational creeds are exogenous factors for the local churches, whether Catholic or Protestant, but they are often not acknowledged.

Besides the basic beliefs, the basic moral codes are also exogenous variables for local parishes, because some basic moral codes are propagated by the social media and enshrined in customs and laws which necessarily affect churches. Pornography, adultery, violence, false statements, tax evasion, recreational sex or drug use, shopping sprees, indebtedness, same-sex marriages, the use of reproduction technologies, euthanasia, etc. are seldom the topics of sermons, and are seldom discussed between parents and children. It is also so about gender roles. The women's liberation movement has affected churches by raising the issue of the women's ordination; in many churches, the traditional definition of gender roles tends to alienate the younger generation to the point of exit from the church.

A third exogenous variable is public education. While the churches have promoted free education for centuries, today at the world level there tends to be a negative correlation between religious beliefs and educational attainment; (Sacerdote and Glaeser 2001) religious beliefs decline with education. To the extent that schools emphasize the rationality of science rather than that of the humanities, they promote the empirical validation of theories which are not appropriate for religion. Technical rationality tends to undermine religious beliefs, and churches are ill-equipped to counter such rationality.

One more basic exogenous variable is the general distrust of institutions and institutional authority. Since the 1960s, references to the bible or the Koran have little sway, according to Fred Craddock in his 1971 As One Without Authority. In 2019 Americans' confidence in organized religion stood at 36\%, lower than that of the military (73\%), small business (68\%), the police (53\%), and the Supreme Court (38\%), according to Gallup findings (McCarthy 2019). This generalized distrust 
of institutions is acerbated by dissent within churches and the tendency among the young to seek non-religious spirituality.

Why has the Roman Catholic Church become indifferent of the outside factors under the papacy of Pope Francis who is so outstandingly involved in global issues (migration, climate change, rapprochement with Islam)? I would suggest the privatization of the liturgy under this pope. Whether in Saint Peter's basilica or the oratory of the Casa Santa Marta, Francis says Mass in Latin and in a low voice as if it were a private devotion. His daily homilies are devotional; he treats social issues in his public speeches, not in homilies. His daily private Masses have recently been broadcast in France, which signaled an important change. KTO, the only Catholic channel in France, has until recently broadcast only one Sunday Mass in all of France, that of the Notre Dame cathedral, to symbolize the unity of all French Catholics around their central church and its pastor. Things changed at about the time of the Pandemic. Now KTO broadcasts several Masses every day, including that of Pope Francis at Santa Marta. The same happened in Guatemala. Until recently the lay-run Catholic television stations, JesusTV, only broadcast one Mass per week. Now there are two 30-min Masses everyday and two on-hour Masses every Sunday. These Masses have become devotions disconnected from outside factors. So it is in San Rocco and probably in most U.S. parishes.

\section{Conclusion about worship: professionalization and secularization as ideological factors}

The two reasons for studying San Rocco became factors of disappointment: both the devotedness of the people and the high intellectual level of the clergy were obstacles to parish self-awareness. Can we say that professionalization and privatization of worship are ideological factors? The professionalization of the priesthood (regular office hours, office visit by appointment only, Mondays off, etc.) are professional gains but they also serve collective self-interests. The privatization of religion is seen in the secularization literature as a factor of decline. Can it also be factor of self-protection? We must raise the question of ideology at the level of cultural studies.

\section{General conclusion: worship, cultural studies, and ideological factors}

An ideology is a system of belief that fosters individual and collective self-interest. Such belief system may not be conscious. Collective self-protection is not necessarily ideological: any society under attack will defend itself. Self-interest is ideological only when its interest properly understood (as defined by Tocqueville) would require adaptation and change but it is rejected for self-protection.

In cultural studies, the general expectation is that the publication of research will enlighten the public and lead to wise decision-making. Thus, it is assumed that public hearings in Congress will lead to wise laws. However, when $100 \%$ of Republicans and $100 \%$ of Republicans agree or disagree about a question of morality 
(impeachment) and economic policies (the Biden \$1.9 trillion economic package), then ideology seems the only factor at work; it is the ideology of partisan politics. When supposedly the wisest men (and a few women) are so deeply divided on most issues, then the ideological resistance to information must be part of cultural studies.

Ideologies are propagated by the mass media which are mainly financed and controlled by business. Both advertisements and entertainment convey the ideologies of individualism, consumerism, ethnic pride (ethnocentric and even racist at times), basic common religious beliefs (and disbeliefs), social conformity, and loyalty to brand names, sports teams, and political parties. Some of these exogenous variables have penetrated religion and explain why change is impeded at San Rocco, and this is so because ideology has become a main factor in the whole society. The pervasiveness of ideology in church and society is an important conclusion for cultural studies.

\section{Suggestions for future research}

In this paper I found much evidence for parish insularity, that is, the absence of awareness of internal and external conditioning. This type of research can be replicated in other local churches and congregations. Future research would benefit from coordinating similar studies in a great variety of settings, e.g., in evangelical, Pentecostal, Presbyterian, Lutheran, Episcopal, Orthodox, conservative and liberal Catholic churches. A secondary analysis of these partial studies should lead to empirical generalizations of great theoretical value. One would most likely find striking differences between liturgical and non-liturgical services, or between conservativefundamentalist and liberal-progressist congregations, or between salvation versus social justice-orientated churches. Furthermore, it would be of great interest to see how different types of worship deal with the exogenous variables of racism, sexism, homophobia, secularism, consumerism, individualism, political and religious sectarianism, violence and hate speech, and many more. Such studies would bring sociology of religion back into the mainstream of social and sociological questioning, as racism, sexism, homophobia, and violence in many forms are at the center of our national concerns in post-Trumpian times.

Funding There was no funding for the research.

Data availability Research data (interviews) are available from the author.

Declarations

Conflict of interest There was no conflict of interest in this research.

\section{References}

Abbott W (ed) (1966) The documents of Vatican II. The Guild Press, New York 
Adler G, Bruce T, Starks B (eds) (2019) American parishes. Remaking local Catholicism. Fordham University Press, New York

America Magazine, New Plan to Reverse Decline? December 10, 2012 http://americamagazine.org/issue/ 5161/signs/new-plan-reverse-decline/. Accessed 20 Dec 2020

Baggett J (2003) Sense of the faithful. How American Catholics live their faith. Oxford University Press, Oxford

Blau PM, Duncan D (1967) The American occupational structure. John Wiley \& Sons, New York

Bowen M (1978) Family therapy in clinical practice. Jason Aronson, Northvale

Bruce S (2002) God is dead. Secularization in the West. Blackwell, New York

Bullivant S (2019) Mass exodus: Catholic disaffiliation in Britain and America since Vatican II. Oxford University Press, Oxford

Chaves M (2017) American religion. Contemporary trends. Princeton University Press, Princeton

Coriden J, Green T, Heintschel D (eds) (1985) The code of canon law. Paulist Press, New York

D'Antonio W, Davison J, Hoge D, Gautier M (2007) American Catholics today. New realities of their faith and their church. Rowan \& Littlefield, New York

Fred C (1971) As one without authority (4th edition 2001). Chalice Press, St. Louis

Hegy P (2019) Worship a social drama. Wipf \& Stock

Hoge D, Dinges W, Johnson M, Gonzales J (2001) Young adult Catholics. Religion in the culture of choice. University of Notre Dame Press, Notre Dame

Jay DP, Appleby RS, Byrne P, Campbell D (1989) Transforming parish ministry. The changing roles of Catholic clergy, laity, and women religious. Crossroad, New York

Lancaster J (1971) Occupational achievement in Australia and the United States: a comparative path analysis. Am J Sociol 77(3):527-539

Leege D, Gremillion J (eds) (1984) to 1989). University of Notre Dame Memorial Library, Notre Dame, Notre Dame Study of Catholic Parish Life

Legal Information Institute (1965) The supreme court decision, Estelle T. Griswold v. State of Connecticut. https://www.law.cornell.edu/supremecourt/text/381/479 Accessed 20 Dec 2020

Market Research, December 10, 2019. Christmas survey: how much will the average American spend in 2019? https://www.pollfish.com/blog/market-research/christmas-survey-how-much-will-americansspend-in-2019/ Accessed 20 Dec 2020

McCarthy J (2019) U.S. confidence in organized religion remains low. July 8, 2019. Gallup News. https:// news.gallup.com/poll/259964/confidence-organized-religion-remains-low.aspx/ Accessed 20 Dec 2020

O'Connell G (2017) Pope Francis says with magisterial authority: the Vatican II liturgical reform is irreversible. America Magazine, August 24, 2017. https://www.americamagazine.org/faith/2017/08/24/ pope-francis-says-magisterial-authority-vatican-ii-liturgical-reform-irreversible/ Accessed 20 Dec 2020

Orsi R (1985) The Madonna of 115th street: faith and community in Italian Harlem, 1880-1950. Yale University Press, Yale

Pew Research Center (2015) Most Americans believe in heaven and hell. November 10, 2015. https:// www.pewresearch.org/fact-tank/2015/11/10/most-americans-believe-in-heaven-and-hell/ Accessed 20 Dec 2020

Pew Research Center (2017) Religious belief and national belonging in central and Eastern Europe. May 10, 2017. https://www.pewforum.org/2017/05/10/religious-beliefs/. Accessed 20 Dec 2020

Sacerdote B, Glaeser E (2001) Religion and education. National Bureau of Economic Research. https:// scholar.harvard.edu/files/glaeser/files/w8080.pdf. Accessed 20 Dec 2020

Smith C, Lundquist DM (2005) Soul searching. The religious and spiritual lives of American teenagers. Oxford University Press, Oxford

Stark R, Glock C (1970) American piety: the nature of religious commitment. The University of California Press, Berkeley, CA

Taves A (1986) The household of faith Roman Catholic devotions in mid-nineteenth-century America. University of Notre Dame, Notre Dame

Thornton A (1978) Marital instability differentials and interactions: insights from multivariate contingency table analysis. Sociol Soc Res 62(4):572-595

Wikipedia. Family Rosary Crusade (n.d.) https://en.wikipedia.org/wiki/Family_Rosary_Crusade/. Accessed 20 Dec 2020

Zech C, Gautier M, Mark M, Wiggins J, Gaunt T (2017) Catholic parishes of the 21st century. Oxford University Press, Oxford 